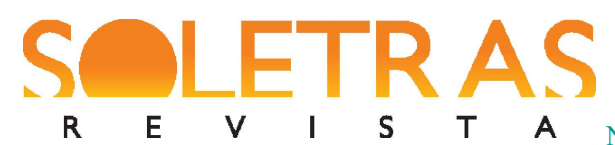

N. 40 - 2020.2 - CLEIRY DE OLIVEIRA CARVALHO

\title{
Um estudo panorâmico dos bolsilivros produzidos para o público masculino: O romance de mocinho
}

\author{
Cleiry de Oliveira Carvalho ${ }^{1}$
}

\begin{abstract}
Resumo: Neste artigo apresento um panorama do romance impresso em papel-jornal e vendido no Brasil a baixo preço para consumo em massa por um público idealmente masculino. $\mathrm{O}$ panorama tem como fundamento a leitura de 101 romances de diferentes coleções e editoras, de seus paratextos, e de fontes secundárias. Ou seja, é um estudo do "romance de mocinho" contemporâneo, inserido em um processo de publicação globalizante; é também uma reflexão acerca da produção de entretenimento, de um lado e, do outro, dos efeitos que esse entretenimento pode provocar no consumidor. As histórias das coleções de literatura narrativa de massa visam a promover determinados interesses econômicos, sem outras preocupações, e submetem seu leitor a um bombardeio de repetições a tal ponto que acabam por criar a necessidade de consumo. As personagens dessas histórias são elaboradas de forma rígida, não mudam do começo ao fim, apenas reforçam uma identidade inicial confirmada a cada prova que ultrapassam. Após analisar os meios e fins da indústria, os esquemas formais e fabulares dessas narrativas, procurando identificar ainda seu leitor ideal, concluo que na própria fórmula literária que se estabelece nesses romances está inscrito o processo de formação de um leitor-consumidor psicologicamente dependente.
\end{abstract}

Palavras-chave: Indústria cultural. Literatura narrativa de massa. Literatura: produção e consumo. Leitura. Romance.

O objeto deste trabalho compreende romances voltados primariamente ao público masculino, apresentados quase sempre como tradução de autores estrangeiros, impressos em papel jornal e pequeno formato, com produção em larga escala e vendidos por reembolso postal, ou em bancas de jornal e sebos de quase todo território brasileiro. Adoto o genérico "romance de mocinho" aproveitando seu duplo sentido: porque são romances protagonizados por heróis não problemáticos, do tipo informalmente conhecido como "mocinho"; e porque o marketing das editoras se dirige explicitamente ao gênero masculino, que se presume projetivamente identificados com o tipo - o "mocinho" como matéria-prima e como depositário do romance. ${ }^{2}$

\footnotetext{
${ }^{1}$ Possui doutorado (2019) em Literatura e Práticas Sociais pelo Programa de Pós-Graduação em Literatura da Universidade de Brasília (UNB), possui graduação (2001) e mestrado (2007) em Letras pela Universidade Estadual de Maringá. Atualmente mantém interesse acadêmico pelas relações entre literatura, sociedade, cultura, história, política e formação social, sobretudo no Brasil. E-mail: cleirycarvalho@yahoo.com.br Orcid: https://orcid.org/0000-0001-6989-4266

2 De modo perfeitamente simétrico, algumas dessas editoras (e outra mais) publicam também "romances de mocinha", em coleções de nome sugestivo, tais como Júlia, Momentos Íntimos, Biblioteca das Moças etc. As coleções "de mocinhos" também recebem nomes sugestivos, como FBI e Chumbo Grosso.
} 


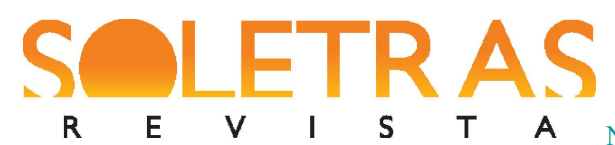

Este panorama é resultado de estudo envolvendo a leitura de 101 romances de mocinho, provenientes de 62 coleções, de 12 editoras diferentes. Convém advertir que nenhuma dessas coleções continua ativa e algumas dessas editoras nem sequer existem mais - quando esse corpus foi formado, em meados dos anos 2000, o mercado de romances de mocinho já era um mercado exclusivamente de livros usados. As mudanças tecnológicas, econômicas e culturais que se impuseram sobre o mercado editorial brasileiro nas últimas décadas foi a pá de cal no fenômeno mercadológico e cultural aqui em tela. ${ }^{3}$ Isso não significa que romances semelhantes não sejam hoje publicados - alguns dos mais prolíficos autores de romances de mocinho continuam, aliás, em atividade. Mas, a par das grandes mudanças nos processos econômicos da esfera da produção e circulação de mercadorias culturais, teria havido também algumas alterações temáticas e formais graças às quais uma nova pesquisa seria necessária antes que se possa extrapolar as observações que aqui faço a literatura narrativa de massa de agora. O romance de mocinho, porém, foi de grande vitalidade durante a quase inteira duração do século XX, o que basta para justificá-lo como objeto de interesse.

\section{A matriz histórica}

Entendo que a expressão "narrativa de provas" descreve notavelmente bem os romances de mocinho, o que nos remete imediatamente aos modos de fabulação da antiguidade grega. Bakhtin (2002), ao investigar a pré-história do gênero romanesco, localiza no romance sofista a origem do romance monofônico, uma vez que alcançou uma "expressão suficientemente completa e acabada" para determinar toda a "história ulterior" do romance europeu. Esse antigo romance de aventuras caracteriza-se como romance de provas, porque as personagens principais passam por inúmeras aventuras e peripécias envolvendo "entraves" que precisam ser superados para que se produza, no desfecho, a feliz união dos apaixonados (BAKHTIN, 2002, p. 214).

Seu herdeiro talvez mais direto surge no século XVII (o romance de viagem), num

\footnotetext{
3 Entre essas mudanças, parecem-me significativas o advento do ebook, o crescimento acachapante da importância social das redes sociais, a atuação agressiva do capital mundializado no mercado editorial brasileiro e a popularização do best-seller estrangeiro pelo cinema (Harry Potter, Crepúsculo, Cinquenta tons de cinza etc.).
} 


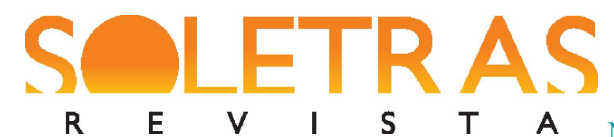

contexto em que se buscavam novo alcance e perspectivas para a ação do homem no mundo. As narrativas de aventuras destacam as capacidades humanas de realização (coragem, determinação, força interior, etc.), instaurando uma ética da ação, que se tornará a força motriz do romance burguês, consolidado no século seguinte. O motivo que orienta as aventuras está fundamentado, na maior parte das vezes, nos valores ideológicos típicos da época.

Deriva do romance de aventuras, já no início do século XIX (MEYER, 1996, p. 57), o romance folhetim, e sua construção, segundo Bakhtin (2002), se dá, de novo, a partir das várias provas por que passam os heróis. $\mathrm{O}$ autor descreve o romance de folhetim como artefato literário simples, dotado de estrutura discursivo-ideológica que se repete em qualquer texto denominado folhetim. Seus traços principais são a linguagem pouco sofisticada; o enredo movimentado e inflacionado de peripécias; personagens e conflitos de constituição maniqueísta; circunscrição social simplificada e livre de contradições. Sua mensagem é patriarcal e seu projeto ideológico atende aos interesses da classe dominante. Sua condição cronotópica não provoca modificação de ordem biológica, social ou psicológica nas personagens. Nos romances de aventura, inclusive nos de folhetim, os heróis não se modificam, embora sejam submetidos a provas e sofram a passagem do tempo. ${ }^{4}$

O folhetim torna-se, graças a seu traço melodramático, uma etapa importante na constituição da fórmula narrativa adotada pela literatura narrativa de massa: o corte sistemático que deve criar suspense; diálogos simples que vinculem o leitor; a simplificação psicológica (para não dizer unidimensionalidade) das personagens; o maniqueísmo na representação do conflito; o mocinho vingador ou purificador; a boa jovem ameaçada ou ultrajada - eventualmente deflorada mas, ainda assim, "pura". Todo este conjunto compõe ingredientes para sedução em massa.

Enfim, essa conjunção que traz para o romance de provas a ética da ação individual autônoma enquadrada pelo melodrama engendra a fórmula produtiva da indústria de entretenimento e veiculada nas coleções de romances aqui discutidas. Aí se põe à prova a força de caráter, a dignidade, a virtude e a determinação das personagens que, ao final, triunfam e, ultrapassando os "difíceis" obstáculos, revelam sua verdadeira natureza.

\footnotetext{
${ }^{4}$ Para Bakhtin, nesse momento a relação com o cronótopo ainda não está historicizada, na medida em que os heróis reforçam o mesmo caráter do início ao fim da narrativa, o que tende a se alterar ao longo do século XIX, período em que uma visão historicista da existência emerge e se consolida.
} 


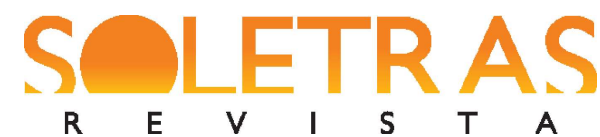

Um modelo paradigmático dessa fórmula se cristalizou no romance de faroeste, majoritário no romance de mocinho, como já disse. Dada a sua penetração no mercado, convém retraçar também suas origens mais específicas, para a qual serve de emblema o romance $O$ último dos Mohicanos, de James Fenimore Cooper.

Mary A. Junqueira informa que os historiadores norte-americanos, em geral, entendem que a lenda do Oeste foi estruturada no século XIX, na literatura. Nesse processo de construção cultural, destaca-se o nome de James Fenimore Cooper (1789-1851), considerado o primeiro autor a estabelecer um repertório de símbolos e uma forma narrativa que constituem as bases desse mito, que seria desde então reescrito constantemente. De acordo com ela:

James Fenimore Cooper publicou o seu primeiro romance, The Precaution, em 1820, inspirado nos trabalhos da romancista inglesa Jane Austin. Em 1821, o autor publicou The Spy, tratando da Independência norte-americana, inspirado em Sir Walter Scott. Enquanto The Precaution não teve apelo junto ao público, o livro The Spy - publicado nos Estados Unidos e na Europa trouxe fama a Cooper, que começava a ser considerado, a partir de então, 'o primeiro autor norte-americano' (Wallace, 1986 e Daly, 1993). Os leitores do jovem país, até então, liam ficção europeia. (JUNQUEIRA, 2003, p. 15)

Segundo os especialistas no tema da fronteira, a série conhecida como Leatherstocking Tales (Contos dos desbravadores), de Cooper, foi central para a construção do mito do Oeste no século XIX, ainda que outros autores também tenham tratado a região como lugar de aventura e ação. Isso explica que o autor de $O$ último dos Mohicanos tenha se tornado tão popular e respeitado como escritor. Essa centralidade se deve a uma série de cinco romances: The Pioneers (Os pioneiros), de 1823; The Last of the Mohicans ( $O$ último dos Mohicanos), de 1826; The Prairie (A pradaria), de 1827; The Pathfinder (O desbravador), de 1840 e The Deerslayer ( $O$ caçador de veados), de 1841.

Autores coevos, como Zane Grey, Louis L'Amour e Elmore Leonard e o alemão Karl May também escreveram histórias do mesmo teor. Karl May inspirou-se em Cooper, por exemplo, e depois foi influência determinante para outro alemão, Carl Laemmle, que fundou a Universal Pictures. Ao contrário do que muitos supõem, o "Faroeste" já existia, portanto, consubstanciado num gênero próprio, há pelo menos meio século antes do advento do cinema. 


\section{O modelo formal}

O discurso no romance é sempre mediado, na medida em que combina outros discursos e gêneros, representando-os. Para Bakhtin, o romance estabelece tensões internas na relação com esses outros gêneros que integra em atitude dialógica, revelando-os em seu caráter limitado, histórico. À proporção que os representa, é também representado por eles, porque quando traz para dentro de si os outros gêneros do discurso, representa-se também a si mesmo em sua limitação e relatividade. Segundo o autor, há dois momentos para o romance em sua trajetória rumo ao romance polifônico: os romances de "primeira linha" e os de "segunda linha". Os romances de "segunda linha" recuperam o plurilinguismo social e o internalizam. Ocorre uma espécie de "literaturização" das falas que passam para o interior do romance. Nos de "primeira linha" prevalece o discurso monológico, comprometido com sua totalidade unificada e sempre igual a si mesma: "Sua principal característica é uma linguagem única e um estilo único”, que exclui qualquer plurilinguismo (2002, p. 171).

A prosa romanesca de "primeira linha" pode ser encontrada na própria fronteira da linguagem exemplificada pelos romances de cavalaria. Nesses romances predomina uma atitude monológica, pois os vários gêneros discursivos passam por um mascaramento a fim de parecerem nobres. E os romances de "segunda linha" parodiam, ironizam e dessacralizam esse estilo enobrecido. Assim, tem-se uma atitude dialógica que não unifica, mas estabelece o conflito devido, em um mesmo enunciado, em que vigora o discurso nobre e o paródico, interrelacionando-se dialogicamente e, com isso, esclarecendo-se mutuamente.

Nesse sentido, pode-se dizer que não há polifonia no romance de mocinho, já que não se vê neles aquele embate de vozes de que fala Bakhtin — ao contrário, neles prevalece a voz conservadora e doutrinária do Estado, da tradição judaico-cristã e dos meios de dominação cultural. De fato, não há, por exemplo, relação dialógica entre a personagem feminina e masculina, ou entre tipos e classes de personagens. É exatamente desse modo que as construções fabulares das narrativas de massa são veiculadas pelo mercado de livros de entretenimento. Seus enredos não permitem perguntar por que viver, são, quase sempre, ostentadores de soluções fáceis, felizes, gratificantes. Assim, esses romances são procurados 
por projetarem um mundo feliz, e não por nenhuma possibilidade de compreensão crítica ou questionamento da "realidade".

Quando as personagens possuem vozes diferentes por sua inscrição social, cultural e econômica diferente, elas são uniformizadas na construção de um discurso que submete aquela que se encontra em desvantagem (cultural, social e financeiramente) à perspectiva daquela outra que representa a posição conservadora dominante no discurso narrativo. Não há um tensionamento recíproco entre posições sociais e ideológicas diferentes, mas, quando muito, o deslocamento de uma personagem que se encontra desfavoravelmente em certo patamar, para outro, superior, que tem, entretanto, para ele um peso normativo. Ou seja, o discurso narrativo é política, cultural e ideologicamente ajustado ao status quo, e reproduz sem problematizar os valores mais tradicionais da sociedade em que vivemos.

Assim, nos termos de Bakhtin, estamos diante de romances "monofônicos". É somente a visão masculina tradicional que prevalece, filtrando e infiltrando todas as outras. Mesmo em enredos que têm a mulher como heroína, o narrador dá um enfoque que suscita a leitura conforme as expectativas do leitor ideal masculino previsto no programa editorial. A voz e opinião das mulheres são apagadas. Ainda que a mulher seja a heroína do romance de mocinho (Coleção Mulher \& Colt, Coleção ZZ7) ela terminará por reproduzir um comportamento projetado para gratificar esse leitor ideal masculino, ou para estimular fantasias masculinas erotizadas. Nesse aspecto, essas coleções podem ser consideradas análogas ao filme pornográfico, porque não estão abertas ao que Bakhtin chama de "multilinguagem".

Já vimos que a fórmula do romance de mocinho se origina do ajustamento do romance de provas à ética da ação individual autônoma enquadrada pelo melodrama. Seus principais ingredientes são a linguagem simples, a baixa complexidade formal, o psiquismo das personagens livre de conflitos — os conflitos são externos, sem contradições e livres de ambiguidades morais: de cá, o herói, a honra, a verdade, a equidade; de lá, o vilão, a ignomínia, a iniquidade, a falsificação. Resumindo, de um lado o bem, do outro o mal. Vimos também que as personagens são sempre já formadas, nunca submetidas a processos formativos ou de mudança - o desenvolvimento fabular funciona como confirmação de sua natureza "verdadeira".

Enfim, as estruturas lineares das narrativas, suas personagens chapadas e um rol 


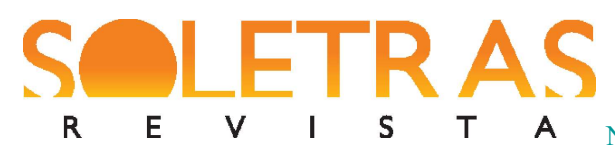

limitado de motivos elementares previstos na luta de superação de obstáculos constitui a fórmula geral, atualizada dentro de uma ambientação e de um contexto histórico, econômico e político particulares e variáveis segundo a coleção, mas sempre carregando e promovendo as concepções e os valores estereotípicos do senso comum conservador (como as imagens de gênero e classe, por exemplo) — esses valores e concepções têm caráter claramente estruturante no romance de mocinho. ${ }^{5}$

\section{A tradição e sua negação}

Como os grandes clássicos da tradição ocidental aparecem no romance de mocinho? Ocasionalmente algumas obras são citadas e alguns autores são mencionados, tais como Victor Hugo, William Shakespeare - nenhum autor brasileiro. Personagens com algum conhecimento da tradição ocidental aparecem eventualmente, mas em nenhum momento os textos clássicos são explorados como entidade autônoma confrontada às narrativas de massa. Encontrei um único caso de mocinho intelectual, em Os eleitos da morte: "escolheu um livro na biblioteca, pensando que no dia seguinte desfaria suas malas e apanharia cadernos e livros que trouxera para trabalhar em sua tese" (BIALLY, 1995, p. 12). Mas esses cadernos e livros, mencionados de passagem na caracterização da personagem, não voltarão a aparecer.

A literatura é, ao mesmo tempo, passado e presente. Mas, no caso do romance de mocinho, seu passado se presentifica de maneira fragmentada. Não é a leitura do texto do passado, com seus problemas específicos, que chega ao leitor, mas sim uma "intertextualidade" mutilada, uma reciclagem esquematizadora de retalhos dos clássicos fagocitados pela indústria de entretenimento. As referências a eles aparecem como adorno ou são instrumentalizadas para cumprir funções banais. Não há, nas coleções estudadas, nenhuma referência a textos lidos pelas personagens que sejam aproveitadas para aprofundar algum estado psíquico conflituoso e, muito menos, para que a cultura dos clássicos e a cultura de massa se confrontem criticamente.

\footnotetext{
${ }^{5} \mathrm{O}$ enredo admite analepses e prolepses, as quais não costumam ser levadas ao ponto de arriscar minimamente a clareza e prevalência estrutural da linha temporal direta. Encontrei um único romance discrepante nesse aspecto: Estranha aventura, de Frank King (1994), apresenta três histórias com o mesmo narrador — que não produzem, porém, nem dificuldade nem estranhamento, porque são individualmente estruturadas como contos policiais. Três contos no lugar de um romance parece uma troca justa na economia do consumo de literatura de massa.
} 


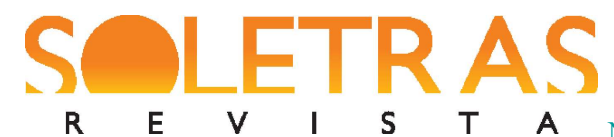

Em Covil do chacal, temos a certa altura um diálogo entre dois homens a respeito de um ser estranho, possivelmente sobrenatural, rondar a região onde moram, conhecida como Quebrada do Chacal, e chacinando pessoas de comportamento condenável para a Igreja. Então um deles diz — "Um grande escritor inglês, certa vez, explicou que no mundo acontecem certas coisas que a nossa filosofia não consegue explicar ou entender" - , ao que a outra completa — "Ele foi William Shakespeare. Este pensamento está em Hamlet e foi dito por Horace, o melhor amigo do Príncipe da Dinamarca” (CURTIS, 1997, p. 63).

Na conversa, a fala de Horácio se converte em postulado de senso comum, perdendo a complexidade que tinha em face dos dilemas de Hamlet. Mais significativamente, o fato de ambas as obras compartilharem o motivo do fantasma, real em Hamlet, produto de fraude em Covil do chacal, fica por conta da cultura literária do leitor, de quem, entretanto, a indústria não espera essa cultura. De fato, se ela fosse pressuposta no leitor ideal, as personagens, para corresponder ao horizonte de expectativas desse leitor, teriam de se lembrar de Dáfnis e Cloé, e do artifício de recobrir-se com pele de lobo (LONGO, 1990). Aliás, nem era preciso, pois a indústria cultural recicla cotidianamente os topos da tradição - o próprio autor de Quebrada do Chacal, Donald Curtis, já publicara pela coleção Oeste Beijo e Bala o título Quebrada do Terror, isso em 1992, cinco anos antes de Covil do Chacal, da coleção Lei do Revólver. Nos dois romances o problema é o mesmo: um homem vestindo pele de urso põe em risco um vilarejo. Por quê? A chave está no fato de que a literatura narrativa de massa fagocita a tradição, mas não produz nenhuma tradição. Sua efemeridade é atributo essencial, como já vimos. Não é síntese, não há subsunção — há assimilação e aniquilação. O que era “experiência" e repertório se converte em "vivência" imediata, não formativa, descartável. ${ }^{6}$

As possibilidades de leitura crítica pela via intertextual são múltiplas, mas não são encorajadas nos processos narrativos. Há no diálogo em discussão, por exemplo, além da hipótese da explicação sobrenatural, outras aproximações possíveis entre o romance e a peça de Shakespeare. Como Hamlet, o mocinho chega ao local da ação na perspectiva de desvendar um assassinato. Porém, não há aproveitamento dialógico ou intertextual de tais ocorrências, há antes o seu apagamento. Com efeito, além de cumprir a função relativamente banal de evidenciar a diferença de opinião entre os interlocutores (um contempla a

\footnotetext{
${ }^{6}$ Uso os termos "vivência" e "experiência" como tradução dos conceitos benjaminianos de Erlebnis e Erfahrung — ver Gagnebin (1994).
} 


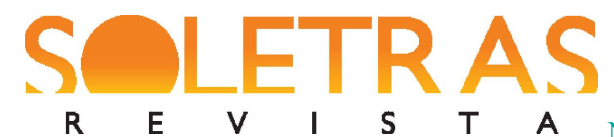

possibilidade do sobrenatural, o outro a rejeita), a referência à tragédia shakespeariana só produz um desvio temático manifestando preconceito: alguém "com aspecto de vaqueiro ou talvez até de..." (pistoleiro?) jamais conheceria Shakespeare "e muito menos o Horace de Hamlet". Diante dessa verdade (?), o outro se vê na contingência de explicar-se, justificando a origem de certo modo fortuita de seu conhecimento da personagem Horácio - "Só por isso sei suas falas de cor”. (CURTIS, 1997, p. 64)

Essa é a relação típica dos romances de mocinho com a tradição. Temas, motivos, peripécias, dispositivos de toda ordem são silenciosamente submetidos aos constrangimentos da fórmula e reciclados nesses moldes. Menção a obras clássicas aparecem, mas de modo instrumental dentro da fábula, e não para de fato remeter o leitor a considerações de ordem intertextual. No máximo, têm papel decorativo, servindo também de insígnia para seu autor, capaz de referenciar os ícones da história literária. Desse modo, a tradição ocidental impregna a narrativa, mas dissolve-se nela e desaparece. Ao mesmo tempo, como produto literário, o romance de mocinho engole a tradição mas não devolve nada, porque a indústria cultural desconhece a ideia de um patrimônio cultural coletivo: como o dinamismo do mercado é tudo, da mercadoria, depois de consumida, o que resta é lixo e deve ser tratado como tal. E isso explica o quanto impróprio seria pensar nos nichos da literatura de massa como uma tradição.

\section{Conteúdo e forma: modelos fabulares}

Um dos métodos produtivos no estudo de objetos de cultura de massa é a análise de conteúdo (Kientz, 1973). Este poderia ser um ponto de partida interessante na abordagem dos romances de mocinho e de suas coleções. Assim, comecei por arrolar as categorias que pude identificar nas narrativas; em seguida, passei a sistematizar os resultados sob a forma de tabelas descritivas das características recorrentes. O procedimento começa por tratar do conteúdo manifesto de maneira quantitativa, mas dessa análise emergem quase espontaneamente questões qualitativas: Como se constituem as diegeses? Qual é a galeria das personagens? Como é construído o herói ou a heroína? Como é construído o vilão ou a vilã? Estas suscitam ainda a outras questões, abrindo, como é frequente na pesquisa, um campo virtualmente inesgotável: qual o significado da indústria cultural e da literatura narrativa de 
massa? Como se dá a escolha, a produção e a publicação dessa mercadoria? O que é possível concluir, a partir da própria constituição das narrativas, sobre a relação que com elas o leitorconsumidor estabelece?

Não é difícil perceber por esse esboço, que o caminho que começa pelo estudo do conteúdo pode levar, com muita eficácia, ao estudo da forma, se quem estuda tiver essa inclinação. Neste panorama, aspectos formais aparecerão, mas não será possível fazer análise detalhada das narrativas.

Direto ao ponto, começo adiantando alguns modelos fabulares recorrentes:

- O mocinho persegue um criminoso em busca da recompensa; ao consegui-la vai embora sem se envolver com ninguém;

- O mocinho é caçador de recompensa, mas depois de conhecer o verdadeiro amor, recebe indulto e passa a viver em harmonia no vilarejo, sendo sempre respeitado pelo seu passado $;^{7}$

- O mocinho torna-se caçador de recompensas ao fugir de seu passado de desilusão amorosa e alguma transgressão involuntária (como matar alguém em legítima defesa);

- A mocinha protagoniza alguma situação de perseguição para defender a honra de sua família que foi dizimada ou prejudicada ${ }^{8}$

- O mocinho (ou a mocinha) é agente da lei que combate o crime, envolvendo investigação e perseguição;

- O mocinho é espião (ou a mocinha, espiã) que salva o mundo de conspirações de malfeitores;

- Um forasteiro e jogador profissional perambula pelo Oeste tirando proveito dos ingênuos até encontrar o amor, e com isso mudar de vida e constituir família;

- O mocinho "salvador" defende índios ou grupos indígenas de agressões e injustiças

\footnotetext{
${ }^{7}$ A condição de caçador de recompensa se bifurca. No vilão ela será uma condição vil. No protagonista, ela é sempre justificada e não o mancha moralmente: ou ele a assume por contingência alheia à sua vontade $\mathrm{e}$ permanece nela com equidade e honradez, ou ele é levado a ela em nome do bem comum. O protagonista nunca será simples assassino, podendo, no máximo, ser matador de assassinos.

${ }^{8}$ Um romance de mocinho pode sem nenhum problema ser protagonizado por uma heroína, embora o inverso não ocorra no romance de mocinha. Quando um romance de mocinho tem uma mulher como protagonista, os modelos temáticos formais dele se impõem no desenvolvimento fabular e na representação dessa mulher e de sua conduta - a mocinha nunca deixa de ser instrumento de erotização na economia dos romances.
} 
praticadas pelas forças antagônicas. ${ }^{9}$

Muitas das narrativas têm início com a chegada dos forasteiros (homens ou mulheres) em algum vilarejo. Os moradores do lugar, em forma de agradecimento pelas "ações de saneamento" feitas pelo "forasteiro", o convidam para ficar; já as forasteiras terminam o serviço e vão embora - caso das coleções Mulher \& Colt (faroeste) e ZZ7 (espionagem) ou ficam no vilarejo e se casam.

Em Jenny “mata-homens” (1987), de Lou Carrigan: no segundo capítulo, a forasteira Jenny chega para falar com o xerife. Ela possui uma lista de pistoleiros e os persegue até matá-los, em busca da recompensa que doa a um orfanato. Ao falar com o xerife, informa que, no distrito de responsabilidade dele, há nove homens procurados no Arizona, Novo México e Arkansas e pergunta o que ele fará. O xerife diz que eles não são procurados no Texas e que nada poderá fazer. Jenny indaga se Malcom Farragut reside na região [este é pai da noiva do xerife] e informa ao homem da lei que está caçando homens para matá-los. Farragut violentara Jenny uns dez anos antes e agora ela está preparada para vingar a morte de sua família e os abusos que sofreu. Após cumprir sua tarefa, ela recebe ajuda do xerife que troca Elaine Farragut por Jenny, aceita o pedido do xerife Clinton para ficar com ele.

Em Encontro com a morte existe uma tentativa de classificar a posição do cinturão como denunciadora da condição do forasteiro:

- Caryl tem razão... Basta ver como é que ele está carregando os revólveres! Ele os traz na cintura com as coronhas viradas para a frente. Ora! Todos nós sabemos que um saque cruzado é muito mais lento e ineficiente do que o saque direto! (MONROE, 1990, p. 54-55)

Olhou para os Colts do rapaz.

Estavam colocados muito alto na cintura com as coronhas voltadas para a frente.

Com os revólveres naquela posição, seria impossível sacar em um saque cruzado, o famoso e ineficiente [?] cross sack.

$[\ldots]$

Mike [o mocinho] não sacaria em um cross sack... Não...

$[\ldots]$

\footnotetext{
${ }^{9}$ A cultura indígena acaba inferiorizada: de um lado é tratada como selvagem e digna de ódio; do outro, como objeto de condescendência paternalista.
} 


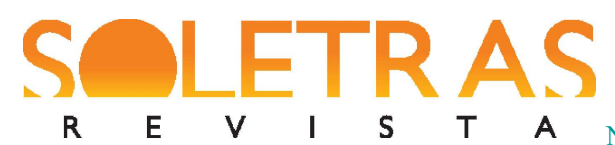

Mike sacaria usando o terrível, o dificílimo e eficientíssimo tipo de saque que apenas os pistoleiros mais afamados usavam: o srew sack, ou saque em parafuso!

Nessa modalidade de sacar as armas, o atirador levava as mãos as coronhas dos revólveres com a palma voltada para fora, os polegares para trás e os mínimos para a frente. A mão direita ia ao revólver da direita e a esquerda ao da esquerda, sem a necessidade de se cruzar os braços à frente do peito.

Um saque muito mais do que veloz...

E extremamente preciso! (MONROE, 1990, p. 68-69).

O uso do revólver é variável de romance para romance. Em um, o uso de dois revólveres pode significar a eficácia daquele que o usa, em outros o fato de usar apenas um revólver demonstra que o atirador é mais eficiente que qualquer um que use dois. $\mathrm{O}$ uso de arma branca demonstra a coragem do pistoleiro, mas apenas em um romance o forasteiro não sabia atirar e usava a faca com eficiência. A faca pode ser usada por índios ou como arma secundária em todos os outros casos.

É muito frequente a ausência da família do mocinho. Ele pode tê-la perdido por assassinato e, sendo o único sobrevivente, resolveu eliminar todos os assassinos. A família pode ser apagada da história. Vejamos um caso em Condenado a viver: "Fui abandonado em uma missão franciscana dessa cidade. Nunca se soube quem eram meus pais. Fui batizado como Juan Santa Fé e um velho caçador chamado Yako foi meu padrinho "(CURTIS, 1997a, p. 20-21).

Também pode acontecer de o pai do mocinho falecer no início da narrativa, mas é mais comum a família ter sido dizimada por algum pistoleiro e, assim, o "herói” está prestes a recuperar a honra dos mortos. São raros os casos de o mocinho ser atingido e correr risco de vida, mas acontece. Um único "mocinho" foi morto em todos os 101 títulos estudados. Em Mulher fatal (1995), de Tony Carson, um policial/investigador responsável pela prisão de uma belíssima chefe do crime organizado se apaixona por ela e, na tentativa de salvá-la, é confundido com um bandido e tem sua vida liquidada. A jovem é presa.

Com um desfecho assim, esse romance atípico de mocinho quebra o padrão da fórmula. De modo geral, nessas histórias a vitória final do mocinho ou mocinha funciona como a consagração dos valores associados à ação transformadora das circunstâncias (nunca da essência) das personagens. O indivíduo é valorizado pela luta que estabelece com o seu meio; pelo código de honra que mantém (melodramaticamente bom), moralmente superior à 


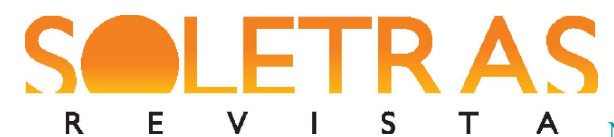

própria lei; pela reputação granjeada por meio de atos de força ou de generosidade (criadora de dependência nas relações humanas). O romance exalta a ação e a reputação produzida por ela como fator legítimo de hierarquização social. A cultura popular mundial, muito influenciada pelos valores da estadunidense, costuma preferir e cultivar uma cultura idealizadora da honra, em detrimento do direito e da lei.

\section{A indústria e seus meios: as coleções, os autores e o "faz de conta" editorial}

Como se tratava de uma indústria em processo de desagregação, foi praticamente impossível obter das próprias editoras as informações que delas esperava receber. A editora Nova Cultural não respondeu à indagação sobre o status das coleções FBI e Super Far West. A editora Monterrey está indisponível há algum tempo, e até seu site saiu do ar em algum momento entre 2003 e 2006 . As demais editoras nem mesmo foram localizadas. Isso posto, a maior parte das informações que pude obter foram recolhidas de fontes secundárias ou das cartas ao leitor e do material publicitário presentes nos próprios exemplares dos romances.

Da editora Bruguera/Bolsilivros, encontrei 18 coleções: Ases do Oeste, Bravo Oeste, Califórnia, Caravana, Desafio, Flama do Oeste, Fúria, Laço, Lei do Oeste, Oeste Bravio, Oeste Heróico, Oeste Selvagem, Rancho, Rifle, Valentes, Vaqueiro, Vingadores e Winchester. A Nova Leitura anuncia as "melhores histórias do Oeste em livro de bolso", em 16 coleções: Arkansas, Ases do Gatilho, Bandoleiro, Chaparral, Coldre, Dallas, Durango, Lei do Chumbo, Montana, Oeste Aventura, Oeste Espetacular, Oregon, Paladino, Pistola, Rota do Oeste e Terra Bruta. A editora Disbra apresenta quatro opções de aventuras do Oeste: Dallas, Dakota, Navajo e Sioux. São 32 as coleções que a editora Cedibra disponibiliza a seu leitor: Arizona, Bala de Fogo, Calibre, Califórnia, Caravana, Coldre, Colorado, Colt 45, Corisco, Cowboy, Desafio, Estefania, Estefania Ouro, Forasteiro, Fúria, Gun Man, Kansas, Kid Ben, Laço, Nebraska, Oeste Bravio, Oeste Legendário, Oeste Selvagem, Pradaria, Ranger, Rifle, Rio Bravo, Terra Brava, Trigger, Valentes, Winschester e Xerife.

Estes exemplos são suficientes para marcar a grande uniformidade temática do romance de mocinho - tudo indica que o faroeste era o modelo mais frequentemente adotado. Outros envolvem guerra, espionagem, crime e detetives, etc. Algumas coleções são 


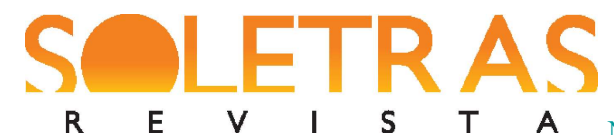

subdivididas em variantes de um tema geral, como a $H H$, da Monterrey, que, além da série básica de histórias de heróis, apresenta três séries alternativas: $\mathrm{HH}$ - Heróis de Guerra, HH$2^{a}$ Guerra Mundial e HH - Epopeias de Guerra. Outras coleções se subdividem em séries identificadas por cor, como estas, também da Monterrey: ZZ7, Chumbo Mortal, Oeste Beijo e Bala e Oeste Brutal. As coleções têm periodicidade definida. Quinzenalmente o consumidor tem as seguintes coleções a disposição no mercado: $F B I$ e ZZ7; a cada 20 dias tem a coleção HH; mensalmente, Chumbo Grosso, Chumbo Mortal, Chumbo Quente, Mulher \& Colt, Oeste Barra Pesada, Oeste Beijo e Bala, Oeste Brutal, Oeste Carga Dupla, Oeste Perigoso, Oeste Pra Valer, Oeste Proibido, Oeste Vermelho, Oeste Vermelho, Oeste Violento, Roleta da Vida e Tiroteio.

No levantamento realizado, a editora Monterrey parece ter sido líder do romance de mocinho, mas a Nova Cultural também marcou presença. Em novembro de 2003, entrei em contato com a editora Monterrey, pela internet (em 2006 o sítio já não mais existia). Na época, obtive resposta de Juan Alberto Fernandez Nunes, por quem fiquei sabendo que a editora estava comercializando os últimos exemplares de títulos já publicados e ainda não esgotados - 15 títulos das coleções Chumbo mortal, Oeste brutal, Oeste carga dupla, Oeste vermelho, Lei do revólver e Reis do gatilho; 14 títulos das coleções Chumbo quente, Oeste beijo e bala, Feras do Oeste e Tiroteio; oito títulos da coleção Mulher \& Colt; seis títulos da coleção Ases do oeste; quatro títulos da coleção Oeste sensual e três títulos da coleção Astros do gatilho.

Chama a atenção o fato de um dos títulos em estoque, Diadema sangrento (autoria atribuída a Curtis Garland), da coleção Oeste brutal, ter ano de publicação 1996. Se num mercado como esse, de produtos efêmeros cujo consumo é estimulado com o recurso deliberado ao desejo e à sedução do novo, as obras podem até ser recicladas, mas jamais reimpressas, parece notável que a editora tenha em estoque um produto lançado sete anos antes! Levando em conta ainda que mercadorias de alto consumo e margem de lucro estreita costumam depender de um ciclo rápido de produção e consumo, é lícito suspeitar de um produto que fica parado por tanto tempo implique prejuízo. ${ }^{10} \mathrm{O}$ fato parece, pois, sinal de declínio do mercado: se a demanda cai substancialmente, não é improvável que o número de

\footnotetext{
${ }^{10}$ Para esse artigo uma nova consulta foi efetuada e não consta, mesmo na Wikipédia, informação sobre o fim da editora. No entanto, essa conclusão é plausível se considero o fato de não existir no mercado de livros edições publicadas na segunda década do século XXI.
} 


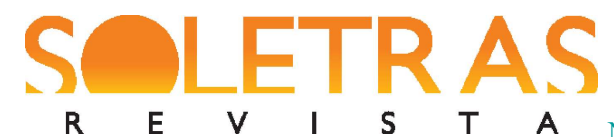

exemplares tirados tenha excedido ao cálculo “do golpe” (ESCARPIT, 1969). ${ }^{11}$

Quanto aos autores, parece-me que analisar separadamente suas produções é trabalho infrutífero - afinal, não só não há marca de singularidade individual, como são, eles mesmos, frequentemente, tão ficcionais quanto os textos a eles atribuídos. Basta considerar os 39 pseudônimos de José Carlos Ryoki de Alpoim Inoue, um médico brasileiro que se consagrou como autor de romances de mocinho. Esse autor, figura, desde 1993, no International Guinness Book of Records, após provar que publicou mais títulos que o espanhol Marcial Lafuente Estefania, até então recordista mundial com 752 títulos. José Carlos Ryoki de Alpoim Inoue, autor de mais de 1.000 títulos, sendo, na maioria deles, para coleções de histórias de faroeste, guerra, policial, espionagem, amor e ficção científica, é responsável pelos pocketbooks publicados no Brasil pela editora Monterrey e outras do gênero (INOUE s.d.).

Circula pela internet que Lou Garrigan é pseudônimo de Antonio Vera Ramírez, conterrâneo de Marcial Lafuente Estefania. Lou Garrigan é autor da coleção ZZ7, com mais de 450 títulos sobre a espiã Brigitte Montfort, e colaborador de outras 120 coleções, com outras centenas de títulos - guerra, espionagem, policial, aventura, faroeste, etc. Outro autor prolífico no universo dos romances de mocinho é o falecido Hélio Soveral, apontado como o autor da série das aventuras do ex-espião Keith Oliver Durban. Mas, para além da pseudonímia e de outros expedientes editoriais - como publicar o mesmo romance em décadas diferentes atribuindo-o a autores diferentes —, há uma fórmula temática, composicional e estrutural cuja autoria é coletiva, sob supervisão e controle da indústria, o que basta para justificar esta abordagem, que não singulariza na análise cada autor individual e sua obra - os escritores são efetivamente trabalhadores de uma indústria que produz uma única, unitária e grande obra, num processo de produção socializada. Essa grande obra, compreendendo romances de mocinho, produz, num único processo, as narrativas e seus autores - o autor como qualidade da mercadoria.

Em contradição com a constituição material modesta dos livros que lhes dão suporte,

\footnotetext{
${ }^{11}$ Desde o começo dos estudos preliminares à fabricação, é necessário 'pensar no público'. Conforme se trata de um livro de luxo, destinado a algumas centenas de bibliófilos, ou de um livro popular barato, a modificação é completa: o papel, o formato, os processos tipográficos (escolha dos tipos, justificação, densidade das páginas, etc. etc.), a ilustração, a encadernação e sobretudo o número de exemplares a tirar. Desde esse momento, o editor deve calcular o 'golpe' que quer realizar. Com efeito, ele até já os devia ter calculado no estado de seleç̧ão: se o livro foi escolhido por estas ou aquelas qualidades, dirigindo-se a este ou àquele público, [...] (ESCARPIT, 1969, 111).
} 
toda a estratégia publicitária relacionada ao romance de mocinho gira em torno da exaltação de seu teor original, atual e exclusivo. Assim, os processos de divulgação acabam por exigir certa dose de cinismo - sobretudo porque a contradição entre o que se anuncia e o que se oferece se manifesta em forma e conteúdo: mesmo uma análise superficial detectaria o padrão fabular e estrutural que lhe é específico e que, em face do fenômeno romanesco em geral, nada tem de original, atual e exclusivo. Vejamos, na tabela abaixo, como a editora Monterrey apresenta suas coleções. Antecipo o fato de essas informações possuírem uma linguagem mais oralizada e por isso apenas reproduzo-as tais como são apresentadas.

Tabela 1 - Dados Coletados das Coleções da Editora Monterrey 


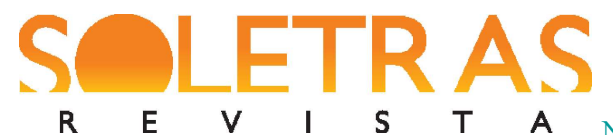

N. $40-2020.2$ - CLEIRY DE OLIVEIRA CARVALHO

\begin{tabular}{|c|c|c|}
\hline Nome da coleção & Gênero informado & Chamada para o conteúdo da coleção \\
\hline $77 Z$ & Espionagem & $\mathrm{O}$ agente irresistível. \\
\hline $\begin{array}{l}\text { Ases do Oeste } \\
\text { Astros do Gatilho }\end{array}$ & Bangue-bangue & $\begin{array}{l}\text { Os únicos exuberantemente ilustrados com belíssimas } \\
\text { gravuras desenhadas pelos melhores artistas, } \\
\text { elaboradas especialmente para nossos leitores. } \\
\text { Experimente o incomparável prazer de ler as mais } \\
\text { eletrizantes aventuras, repletas de ação, emoção e } \\
\text { tensão nas doses certas. }\end{array}$ \\
\hline Chaparral & Bangue-bangue & O bangue-bangue da televisão. \\
\hline Chumbo grosso & Bangue-bangue & Aventuras inéditas do oeste bravio. \\
\hline Desirée & Romance & O amor nascendo do ódio. \\
\hline$F B I$ & Policial & A melhor novela policial do mundo. \\
\hline Gangs & Policial & $\begin{array}{l}\text { Histórias inéditas da máfia. Os sindicatos do crime. } \\
\text { Tráfico de droga. Assassinato. Impressionantes relatos } \\
\text { do submundo organizado em verdadeiras GANGS de } \\
\text { marginais. }\end{array}$ \\
\hline$H H$ & Guerra & O episódio que não foi escrito. \\
\hline K.O.Durban & Espionagem & A espionagem em Bossa-Nova. \\
\hline Mulher \& Colt & Bangue-bangue & $\begin{array}{c}\text { Giovanna Mountain, agente } \mathrm{n}^{\circ} 1 \text { do Special Security } \\
\text { Service do governo americano. Bela e sensual repórter, } \\
\text { impõe a lei no Oeste entre assassinos e ladrões de } \\
\text { gado. }\end{array}$ \\
\hline $\begin{array}{l}\text { Oeste beijo e bala } \\
\begin{array}{c}\text { Oeste beijo e bala: série } \\
\text { vermelha }\end{array}\end{array}$ & Bangue-bangue & O velho Oeste com pólvora e sensualidade. \\
\hline $\begin{array}{l}\text { Oeste brutal } \\
\text { Oeste brutal: série } \\
\text { magenta }\end{array}$ & Bangue-bangue & Um far-west violento. \\
\hline $\begin{array}{l}\text { Oeste carga dupla: série } \\
\text { amarela }\end{array}$ & Bangue-bangue & $\begin{array}{l}\text { Um bangue-bangue excepcional. Também como uma } \\
\text { balada de incidentes perigosos no Oeste. }\end{array}$ \\
\hline Oeste perigoso & Bangue-bangue & $\begin{array}{l}\text { Violência, pólvora e heroísmo. Também como } \\
\text { emocionantes aventuras do velho Oeste. }\end{array}$ \\
\hline Oeste pra valer & Bangue-bangue & $\begin{array}{l}\text { Um faroeste cheio de emoção do princípio ao fim. } \\
\text { Mercenários regiamente pagos trabalham ao amparo da } \\
\text { justiça, usando a inteligência, os punhos e os } \\
\text { revólveres, no combate sem trégua aos fora da lei no } \\
\text { velho oeste. Histórias eletrizantes e violentas, bem ao } \\
\text { gosto do leitor do gênero western. }\end{array}$ \\
\hline $\begin{array}{l}\text { Oeste Vermelho: série } \\
\text { verde }\end{array}$ & Bangue-bangue & Um far-west mais pra frente. \\
\hline Tiroteio & Bangue-bangue & Uma visão íntima dos cow-boys temerários. \\
\hline$Z Z 7$ & Espionagem & Emoção do princípio ao fim. \\
\hline ZZ7: série azul & Espionagem & Brigitte Monfort em ação. \\
\hline
\end{tabular}


Esse modo hiperbólico de apresentar ao consumidor esses produtos não é exclusividade dessa editora: a Cedibra apresenta a coleção $O$ Coyote como a de um heroico e indomável justiceiro. O vocabulário e o tom dessa divulgação de produtos são facilmente verificáveis nos próprios exemplares das coleções. Mas também não é difícil demonstrar seu elemento deliberado de falsificação. Na quarta capa de $O$ dragão de ouro, da coleção Tiroteio, constam as seguintes informações:

As coleções Ases do Oeste e Astros do Gatilho [são] os únicos [bolsilivros] exuberantemente ilustrados com belíssimas gravuras desenhadas pelos melhores artistas, elaboradas especialmente para nossos leitores. Experimente o incomparável prazer de ler as mais eletrizantes aventuras, repletas de ação, emoção e tensão nas doses certas. (CURTIS, 2000)

De fato, essas coleções apresentam ilustração no início de cada capítulo. As ilustrações são em preto e branco, com variáveis $(3.7 \mathrm{~cm} \times 3.4 \mathrm{~cm} ; 4.3 \mathrm{~cm} \times 3.2 \mathrm{~cm})-$ mas isso não é característica exclusiva das duas coleções, o que se percebe inclusive em $O$ dragão de ouro, o mesmo romance em cuja quarta capa está impressa a alegação. Ilustrações semelhantes foram observadas em títulos como Amor selvagem (coleção Oeste Beijo e Bala), O pau comeu no Kansas (Reis do Gatilho), O filho adotivo (Oeste Vermelho), Rurais do Texas (Lei do Revólver), Pólvora e desejo (Oeste Sensual), Trem da morte (Feras do Oeste), além de tantos outros.

As ilustrações nem mesmo são exclusivas, no sentido de serem representações singulares das histórias singulares a que se associam. A ilustração que aparece na página 61 de O pau comeu no Kansas é a mesma que está na capa de Punhos de aço (coleção Oeste Perigoso), exceto pelos detalhes de que uma está espelhada, e de que a que figura na capa foi impressa em cores, e a outra em preto e branco, como é usual nesse mercado. Essa repetição de ilustrações é frequente. Nos títulos Rurais do Texas e Amor selvagem, respectivamente nas páginas 63 e 75, a ilustração é a mesma; a única diferença consiste na dimensão delas: a primeira mede $2.7 \mathrm{~cm} \times 3.2 \mathrm{~cm}$ e a segunda $3 \mathrm{~cm} \times 3.2 \mathrm{~cm}$.

Esse elemento de repetição é estruturante no processo produtivo das editoras voltarei a isso. Antecipo aqui o tema apenas para apontar que o prometido pelas coleções - e 


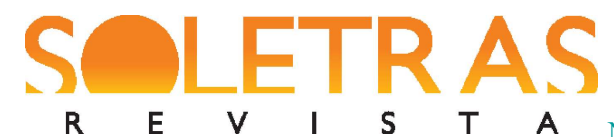

prometem muito - é contradito pelo oferecido. Se isso não aparece para o público é porque toda a relação que se estabelece entre as editoras e seus leitores é revestida pela ficcionalização. O fato de a maioria das coleções tematizarem o "velho Oeste" é significativo por muitas razões, mas o que é emblemático e as identifica com a classe do romance de mocinho é o caráter não-brasileiro das fábulas e de suas premissas históricas e sociais. Com efeito, a ambientação brasileira está, por projeto, excluída - todas as narrativas, quer sejam de crimes, espionagem, romance ou, caso majoritário, bangue-bangue, são narrativas de alhures.

Isso explica o "faz de conta" da origem do texto, que inclui o de sua nacionalidade. Tanto a editora Monterrey quanto a Nova Cultural apresentam seus romances como traduções e muitos, de fato, parecem sê-lo. Por exemplo, o título Vidas Truncadas, da coleção FBI (Nova Cultural); no livro consta o "título original" Vidas truncadas (traduzido por Heral A. Silva) e o copyright da Editorial Andina, S. A., Espanha. Do mesmo modo, A caminho da forca, da coleção Chumbo quente (Monterrey), ao que tudo indica, é tradução (atribuída a Giasone Rebuá) de Un camino hacia la horca.

Já o título Tudo pela Bélgica, da coleção HH Epopeias de Guerra (Monterrey), tem a autoria de um brasileiro, José Carlos Ryoki de Alpoim Inoue, e não apresenta indicação de tradutor; a autoria, porém, é atribuída ao pseudônimo Bill Purse, nome de traço adventício sugestivo de uma origem estrangeira. Não é casual que os 39 pseudônimos de Ryoki Inoue tenham sido exigência das editoras, assim como os nomes das personagens e a contextualização histórica das narrativas (INOUE s.d.) - tudo faz parte do programa de remeter o leitor a um mundo outro, apartado de suas realidades presumivelmente pobres de gratificações. Por aí pode-se já entrever que o faz de conta editorial tem, do lado do consumidor, a contraface da complacência.

A ficcionalização da relação das editoras com o público de fato se espelha na deficcionalização da própria obra para o leitor. A fantasia da obra contamina a apreensão da realidade objetiva de modo particularmente eficaz quando a autoria do romance é atribuída, desde a capa do livro, a seu protagonista ficcional. É o que se observa na coleção $K$. $O$. Durban, narrada em primeira pessoa pelo antigo espião de mesmo nome: os livros podem omitir inteiramente a autoria, como podem estampar na capa o nome do autor fictício, 
efetivamente a personagem que dá nome à coleção inteira. ${ }^{12}$

\section{Mocinhos e mocinhas}

Apesar de não serem a maioria, não são poucas as coleções que se dedicam exclusivamente às aventuras de um único mocinho ou mocinha. Nesses casos, como se trata sempre do mesmo mocinho ou mocinha, suas descrições físicas e comportamentais se diluem, e não são sempre retomadas em todos os números - o consumidor adquirirá nas leituras o repertório de informações sobre as personagens. É verdade que ao adquirir um exemplar dessas coleções, o consumidor não é obrigado, para compreender a história, a providenciar os números anteriores - de fato, uma história não está amarrada à anterior e à seguinte tal como os capítulos de uma novela. No entanto, há mecanismos fortes de sedução para o consumo. No romance número31, por exemplo, o autor faz alusão a algum elemento, por exemplo, do número 7; em nota de rodapé, esclarece rapidamente o fato e convida o leitor a procurar o episódio referido. Assim, cria-se o entendimento de que quanto mais histórias o consumidor tiver lido, melhor entenderá as que vier a ler, porque essas leituras ficam como lastros para o repertório daquele que segue as aventuras de uma personagem que se repete em tantos números. E isso, sem correr o risco de frustrar (e com isso talvez afastar) o consumidor em razão de um não fechamento da história, da não resolução de uma tensão em que o leitor investiu afetos. Por aí se vê que os meios da indústria de criação e manutenção da pujança do mercado não deixa incólume a esfera composicional - a racionalidade econômica ajusta na minúcia a elaboração literária que, no processo de maximização da eficácia econômica, não pode senão reduzir-se a fórmula. Uma fórmula de máxima eficácia para cada nicho no mercado de literatura de massa.

A maioria das coleções estudadas, porém, não possui herói ou heroína fixos. São romances em geral tematicamente independentes quanto às personagens e situações — nesses casos, os romances se agrupam em coleções apenas segundo a classificação genérica adotada

\footnotetext{
12 Dessa coleção tive acesso somente a Atentado em Pequim 2, que apenas omite qualquer autoria, mas a capa de Atentado em Pequim 1 ostenta "K. O. Durban" — nome do protagonista - no lugar do nome do autor. Naquele a que tive acesso e que omite o nome de seu autor, consta, no entanto, uma chamada publicitária para Atentado em Pequim 1, na forma de uma carta assinada, de novo, por K. O. Durban.
} 


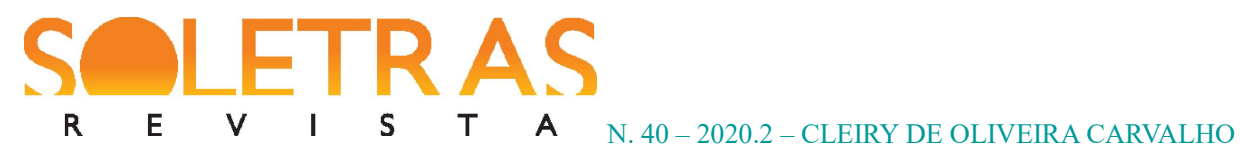

pelas próprias editoras: espionagem, faroeste, policial, ficção científica, etc.

Essa independência admite, porém, o reaproveitamento de personagens, como se dá nos romances de bangue-bangue $O$ rodeio que não houve, Cidade dos diabos e $O$ pau comeu no Kansas, atribuídos a Tadeu Romano, sem especificação de tradutores. Romano aproveita a caracterização de 5 ou 6 personagens, nenhuma delas protagonista, e as usa nas três histórias. Esse fato nos lembra a afirmação de Propp sobre o conto maravilhoso, que teria "uma particularidade: as partes constitutivas de um conto podem ser transportadas sem nenhuma mudança para outro conto" (PROPP, 1983, p. 43).

A coleção K. O. Durban apresenta as aventuras de um antigo espião de guerra, o herói Keith Oliver Durban. A história é narrada por ele mesmo, na primeira pessoa do singular. Também a coleção Detetives é narrada na primeira pessoa do singular pelo protagonista Vic Parr. Ao menos é isso que se dá nos dois títulos a que tive acesso: Os Hippies voam alto (20) e Apoie seu criminoso local (32), ambos protagonizados e narrados por ele.

A coleção $O$ Coyote apresenta as aventuras de Don César de Echagüe, conhecido como Coyote. Um nobre que faz serviços de pistoleiro, mas não é pistoleiro; a função dele é "limpar" o mal, esteja onde estiver. Dos três exemplares lidos pude constatar que existe uma sequência da vida de Don César. Por exemplo, em O falso Coyote (7), Don César está viúvo; em $O$ sequestro (32), Don César já está casado e a história narra o nascimento da filha e a adoção de um menino e, em $O$ diadema das oito estrelas (54), observei que o filho do primeiro casamento ajuda Don César nos afazeres do Coyote. As histórias, no entanto, não são continuações umas das outras: cada um têm sua ação conclusa e suas tensões resolvidas num único volume.

A coleção ZZ7 tem por heroína Brigitte Montfort. Em seus três títulos que estudei as histórias eram também completas e independentes. Contudo, há alusões entrecruzadas: no título Relações públicas (95), na página 9, a história dá pretexto para se remeter o consumidor para dois outros títulos — O raio hidro (65) e Uma brincadeira divertida (77).

Mulher \& Colt é outra coleção que possui heroína fixa. Giovanna Mountain figura nos exemplares lidos como a justiceira de um território árido e tumultuado por bandidagem. Em Desejo louco (2), Trindade diabólica (9), Ouro, bala e sangue (11) e Falência criminosa (17), observei que a essa mulher foi "dado" o poder de resolver todas as ações criminosas que não são resolvíveis pelos homens. 


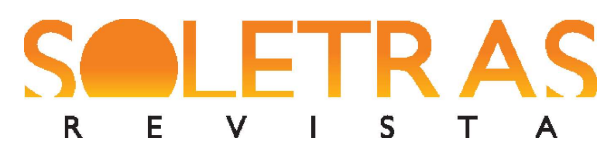

ZZ7 e Mulher \& Colt são as duas coleções protagonizadas por mulher. No entanto, essas mulheres, apesar de desejadíssimas por todos os homens, são possuidoras de um amor único. Independentemente de serem bajuladas por outros homens, são fiéis aos seus respectivos amados. O inverso, por exemplo, é notado na coleção $K$. O. Durban. Nela, o protagonista Keith não só possui uma noiva para cada dia da semana (úteis), como não dispensa a oportunidade de um envolvimento sexual. No caso dele a "fidelidade" é a de voltar para as suas noivas. Isso diz muito sobre as relações de gêneros tomadas como premissa nos romances de mocinho (há nesse ponto diferenças entre o romance de mocinho e o de mocinha, que não cabe aqui detalhar).

Aqui os mocinhos são sempre altos e fortes; ostentam com frequência alguma cicatriz, marca de coragem e honradez. Em Dólares por um corpo, lemos: "Devia ter cerca de trinta anos, aspecto viril, cabelos castanhos claros e olhos cinzentos. Media, pelo menos, um metro e noventa e seus braços eram fortes, musculosos, assim como o tórax amplo" (ADDO, 1979: 8). A aparência é sempre sedutora, máscula, ainda que marcada pelo sol escaldante e a vida difícil. Normalmente possuem entre 20 e 39 anos, são solteiros (o único casado é o protagonista da coleção $O$ Coyote) e podem vir a casar ao término da "missão". São os responsáveis pelo cumprimento da Lei ainda quando não são “a Lei” (xerifes). Exímios atiradores, quase sempre usam dois revólveres.

Quanto às personagens femininas, são frequentemente mulheres fortes $\mathrm{e}$ capacitadíssimas no uso de armas. Por exemplo, lemos em Sede de sangue - "Norma é o melhor vaqueiro do Rancho Shannon. Atira com as duas mãos e monta a cavalo melhor que o mais antigo de seus homens. Dizem que não tem coração e age como homem" - e um pouco adiante - "ela o demitiu [Allan Dewey] marcando-lhe o rosto com um chicote" (MACKENZIE, 2004, p. 28).

A beleza da mulher é sempre apontada, mas de variadas maneiras. Em Um pecado atual encontramos: "Tornou a olhar para ela [Gertrudes], observando-a da cabeça aos pés. Achou-a bonita, sem enfeites nem falsificações" (ORTUSOL, s/d, p. 30). Os sinais que elas emitem diante de um homem que as interesse recebe colorações de ímpetos carnais - em Fui capitão do Afrika Korps: "Ela me olhou e notei que seus seios, firmes e eretos sob o uniforme branco, tremiam como palmeiras agitadas pela brisa do entardecer" (SAAVDROVITCH, s/d, p. 39). 


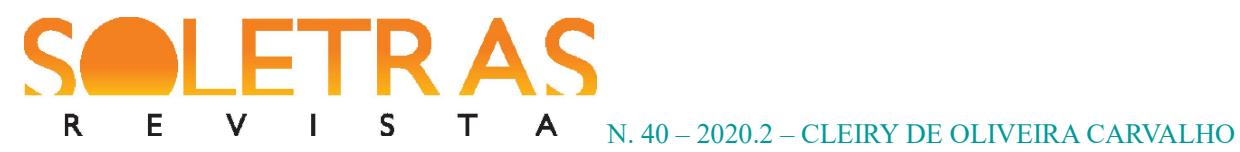

Os sonhos e os padrões de comportamento para uma mulher também são apontados em Herança amarga:

\begin{abstract}
A garota alimentara durante anos o sonho de um príncipe encantado, de um homem especial que correspondesse a suas aspirações de adolescente. Esse homem nunca apareceu em Grangeville e Margareth acabou conformando-se com um destino igual ao de tantas outras jovens que casavam com vaqueiros todos iguais, com as mesmas ambições, os mesmos sonhos, os mesmos projetos.

A garota [...] aprendera com a mãe que o papel da mulher é submisso, de aceitação ao que o destino e o marido determinam para ela. Rebelara-se contra isso na adolescência, mas acabara aceitando resignadamente, perante a impossibilidade de modificar as coisas (COMBY, 1980, p. 8-9).
\end{abstract}

Margareth terá por esposo um bom homem e ele será assassinado logo após dizer o “sim” para o reverendo, antes de saírem da festa. No entanto, o 'detetive' responsável pela investigação da morte do marido de Margareth corresponderá ao príncipe encantado com quem ela tanto sonhou na adolescência - "Para trás ficava um passado sem horizontes, semeado de violências e dor. Pela frente abria-se todo um futuro brilhante, com suas incertezas e dificuldades, mas consciente, apoiado nos sentimentos sinceros dos dois jovens" (COMBY, 1980, p. 125).

A união matrimonial é comum no romance de mocinho, embora menos frequente que no de mocinha praticamente, em que ela é praticamente mandatória. Nos dois casos elas reafirmam duas situações complementares na tradição patriarcal: o lar é/deve ser a esfera de ação/preocupação da mulher; o espaço público é/deve ser a esfera de ação/preocupação do homem. Ou seja, as narrativas incutem uma divisão política tradicional, com um evidente alijamento das mulheres das discussões dos aspectos políticos (da pólis) mais relevantes na sociedade e na cultura.

Ao traçar o perfil dos heróis e heroínas dos romances de mocinho, constatei que mesmo quando a narrativa quer dar a entender que passaram por alguma transformação, não há realmente um processo de transformação dentro do desenvolvimento fabular. Algumas narrativas possuem personagens que permitem saber que o herói, ou a heroína, vivenciaram algumas mudanças e essas são as razões que justificam determinadas atitudes comportamentais adotadas no convívio com a sociedade ou a relação com o sexo oposto, mas 
não encontrei sequer um exemplar que apresentasse um protagonista em formação. Ao contrário, quando há mudança, a mudança é sempre pretérita, e as narrativas apresentam a personagem já modificada, nunca na duração do processo. No máximo, o enredo disporá um "antes" e um "depois", com algumas passagens do tempo "durante" retomadas em retrospectiva. Expandir as incertezas do "durante", que permitiria contemplar a formação da personagem, não é o procedimento nessa modalidade de narrativas.

Referindo-se às modalidades de romances que excluem a polifonia, Bakhtin explica que nelas "o enredo, a composição e toda a estrutura interior do romance postulam essa imutabilidade, essa firmeza da imagem da personagem, o aspecto estático de sua unidade". $\mathrm{Na}$ "fórmula do romance" ela é "grandeza constante", ao passo que todos os demais "elementos da vida e do destino da personagem" aparecem como "variáveis":

de miserável ele se torna rico, de vagabundo sem linhagem se torna nobre; o herói ora se afasta, ora se aproxima do seu objetivo - da noiva, da vitória, da riqueza, etc. Os acontecimentos mudam o seu destino, mudam a sua posição na vida e na sociedade, mas ele continua imutável e igual a si mesmo (BAKHTIN, 2003a, p. 218-219).

A descrição de Bakhtin citada neste trecho se confirma no romance de mocinho. Tudo o que a personagem alcança é representado como simples realização de sua verdadeira essência, presente desde o início e apenas confirmada a cada prova que ultrapassa. Elas não apresentam complexidade existencial e estão em sintonia com o ambiente em que vivem. Elas se deparam com percalços e têm contratempos, que não geram, entretanto, nenhum conflito interior - os conflitos são exteriores e resolvidos de maneira descomplicada. As personagens, ainda quando protagonistas, não vivenciam nenhum dilema que as leve a questionamentos ou estados de fuga. E, como nos contos de fadas, têm seus esforços recompensados por um final feliz.

\section{À guisa de conclusão: repetição, esquecimento, manipulação}

Para Günter Kunert (1970), o mercado editorial, ao inundar de livros a vida literária 


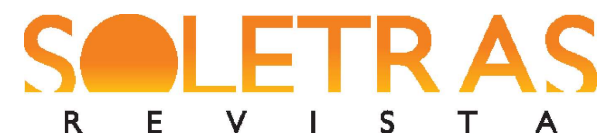

para além da capacidade de leitura de qualquer consumidor, acaba por produzir nele o esgotamento da curiosidade. $\mathrm{O}$ argumento é persuasivo, mas para uma indústria que, como a dos romances de mocinho (ou de mocinha), depende, para subsistir, de um público de leitores ávidos, votados ao consumo frequente de novas aventuras, a capacidade de reproduzir eficazmente a curiosidade é atributo indispensável. ${ }^{13}$

De que os romances de mocinho e de mocinha são produtos efêmeros, dá testemunho a constituição material pouco durável dos livros. O uso do papel-jornal, evidentemente, é decisão natural, decorrente da necessidade de redução de custos de um produto feito para ser consumido com frequência e que por isso deve ser oferecido a preço baixo. Mas justamente nessa materialidade do papel revela-se o parentesco econômico: o jornal deve ser consumido sempre e assim que publicado - amanhã perderá seu valor de uso, exceto, para um público restrito, como documento histórico. No entanto, no caso dos romances de mocinho e mocinha, emerge um mercado secundário de livros usados, mediante compra e venda e até escambo, a partir de uma subcultura de leitura que se movimenta nos sebos e nas bancas de jornal, quase nunca na editora. Obviamente isso não interessa às editoras e a baixa durabilidade deixa de ser simples efeito colateral da redução de custos: torna-se instrumental.

Nesse sentido, a mercadoria precisa ser um impresso datado, como o jornal. E como o jornal, o tempo deve apagar sua existência singular. Sua efemeridade torna-se traço essencial. E justamente essa efemeridade abre outra frente de redução de custos: a reciclagem editorial. Com efeito, esses romances podem voltar como atuais, reimpressos, sem memória de sua origem, sem informação de reimpressão ou reedição. Sua datação se expressa necessariamente como atualidade - atualidade de objeto efêmero cuja existência evapora-se no momento em que o leitor fecha o livro para abrir o próximo.

Desse processo de reciclagem dá exemplo o caso de Duelo en la sombra. Em 1988, a editora Monterrey publicou, como o número 73 da coleção Chumbo Quente, o título Legado maldito, de autoria atribuída a Peter Kapra e tradução de Sebastião da Cunha e Castro Filho (título original Duelo en la sombra). Em 2004, a mesma editora publica, como o número 25 da coleção Reis do Gatilho, o título $O$ garanhão, de autoria atribuída a Lilly Tillbit, sem

\footnotetext{
${ }^{13}$ Não tenho dados sistemáticos sobre os leitores de romances de mocinho, mas as informações que tenho sobre o romance de mocinha dá evidência de uma rotina de leitura de traço obsessivo, em que a leitora inicia um novo romance mal tendo terminado a leitura do anterior. Parece lícito inferir, dada a equivalência dos procedimentos editoriais e mercadológicos da indústria de romances de mocinho e de mocinha, que algo semelhante ocorra entre os leitores de romances de mocinho.
} 
indicar tradução, mas indicando o mesmo título original. As capas dos dois volumes foram ilustradas respectivamente por Benício e Perón Silva.

Em Legado maldito a narrativa começa assim:

O coice de um garanhão selvagem pôs fim à vida de um grande criador, $\mathrm{e}$ plantou a semente do ódio entre várias centenas de pessoas, o que produziria uma feroz e encarniçada luta em que o povoado seria arrasado até seus alicerces.

Um coice talvez aplicado pelo próprio diabo!

O garanhão, casualmente, chamava-se Demon e o criador Ray Warner (KAPRA, 1988, p. 5 - grifos meus).

Em O garanhão, tem-se:

$\mathrm{O}$ coice de um cavalo selvagem matou um grande rancheiro e semeou o ódio entre centenas de pessoas, o que provocaria uma batalha feroz e um povoado seria totalmente destruído. Um coice dado, talvez, pelo próprio diabo!

O cavalo, casualmente, chamava-se Demon, e o rancheiro, um veterano das pradarias, Ray Warner (TILLBIT, 2004, p. 5 - grifos meus).

A mesma história, apresentada com título e autoria diferentes, sofre, textualmente, alterações insignificantes. De qualquer forma, existe um padrão que se caracteriza por sistemas de produção verticalmente integrados, que alimentam crescentes pesquisas internas no sentido de descobrir o que o público quer consumir. A produção, rígida, em concentrações industriais, resulta de uma articulação em redes que agregam numerosos autores que se adaptam às mudanças contextuais. Na organização da produção ocorre uma concentração dos meios de produção (social e espacial) associada à produção em série para os mercados de massa (grande escala), com redução de preços, sempre com a intenção de ampliar o mercado de consumo. Na produção, a divisão entre o trabalho de inserir o produto no mercado e o trabalho de criação está subordinada à concepção do produto, resultante de pesquisa mercadológica temático formal.

Mas em termos de custos, repetir é muito mais eficiente do que reciclar. E se um produto já provado no mercado atende aos requisitos da demanda projetada, e dado que o 
mercado da literatura narrativa de massa aqui discutida se fundamenta no esquecimento do já consumido, por que não o repetir como atual? De fato, isso pode ser confirmado pelo exame do histórico de publicação das coleções.

Em 1981, a editora Monterrey publicou, como o número 17 da coleção Mulher \& Colt, o título Falência Criminosa. Nele há a divulgação dos 16 números publicados anteriormente — ou seja, todos antes de 1981. Investigando o portfólio posterior da editora, constatei que, em 1999, o título número 2, Desejo louco, é republicado; em 2002, foi a vez de republicar o título número 9, Trindade diabólica e, em 2004, o mesmo se deu com o número 11, Ouro, Bala e Sangue. Informações de reimpressão ou reedição omitidas - por premissa as publicações são sempre atuais. Comparando as duas publicações de Desejo louco, observo diferenças cosméticas: a figura da heroína, que na edição mais antiga tinha cabelos crespos, foi atualizada na publicação mais recente: seus cabelos agora foram alisados.

Todos esses expedientes precisam ser revestidos de outra aura, resultante de uma intervenção mercadológica específica. A comunicação direta com o leitor de tom afetivo e laudatório é a tática fundamental. Os livros trazem sempre chamadas que exaltam as coleções e seus títulos, além de cartas ao leitor.

Cabanhe assina o único artigo que encontrei sobre os romances de mocinho — "A Leitura popular dos romances de farwest em Campo Grande: o texto e seu uso" (2004). Nele, focaliza as práticas de leitura de romances de farwest mediante uma análise semiótica. Empresto sua leitura de uma carta ao leitor publicada no romance Escravos da Cobiça, de Tony Charles, editora Publimaq (o pesquisador não informa data de publicação). Cabanhe apresenta a carta já avisando que ela é apelativa. Eis a carta:

Prezado leitor

Os livros de bolso também subiram de preço. E subiram muito. Todavia, ainda continuam sendo vendidos a um preço inferior ao de um maço de cigarros de custo médio. Editar livros de bolso há muito deixou de ser um negócio regular; bom nunca foi, para ser a continuação de um costume, uma devoção, quase uma paixão.

Enquanto tivermos fôlego para editá-los, nós os mandaremos para todos os rincões do país, esperando que nossos amigos leitores continuem a nos prestigiar com sua preferência $(2004$, p. 56).

Cabanhe assinala que a estratégia de manipulação do leitor é clara. O editor (ou sua 
figuração) começa de maneira formal com "prezado leitor" e logo após faz uso do "amigo". A leitura é crítica e levanta questões relativas ao uso do poder pela editora. Empresto de Cabanhe, ainda, a informação quanto aos leitores reais encontrados por ele:

O que nos parecia uma literatura masculina revelou-se, para nossa surpresa, que o é, também, preferência do público feminino. Constatamos que essa leitura é rotulada como cultura inútil, de pouco prestígio. Essa constatação se deu quando os individuos leitores, procurados para esta pesquisa, evitavam admitir o gosto por essa prática. Esse contingente de leitores é composto por militares, aposentados, mototaxistas, cobradores de ônibus, balconistas e alguns estudantes (2004, p. 57 - grifos meus).

A surpresa, a meu ver, decorre de um mal-entendido: a caracterização dos romances como de mocinho ou de mocinha não pode ser entendida como implicando exclusividade de gênero na leitura real - implica antes que um leitor ideal de gênero masculino ou feminino é premissa seminal na elaboração da fórmula. O que Cabanhe observa para o romance de mocinho é também verdade (simetricamente) para o de mocinha — sem surpresa e sem paradoxo.

A construção do discurso romanesco parte de pesquisas elaboradas pelas editoras e se legitima na compra desenfreada, como se fossem absolutamente originais, de produtos extraordinariamente similares. A produção de narrativas de massa é comandada por uma estrutura que modela o mercado e as condições de recepção são antecipadas como parte das condições de produção. Essa antecipação é um cálculo deliberado, possibilitado pelo conhecimento acumulado na prolongada experiência no mercado de livros. Seu propósito é dirigir (e até produzir) a aceitabilidade dos produtos. Com isso, a literatura narrativa de massa funciona em termos semelhantes aos das telenovelas, porque respondem a procuras "diferentes" no mesmo mercado de narrativa de massa. A indústria cria e depois atende a uma demanda objetivada por si mesma. Essa demanda não é uma variável independente e surge por uma série de condições econômicas, sociais e históricas, que produzem tanto as mercadorias, quanto seus consumidores.

Convém ressalvar que esses produtos não se vinculam com o universo do leitor sempre de uma maneira superficial. Às vezes, envolvem estratégias fabulares que parecem históricas em contraposição aos clássicos, que costumam trazer mundos estranhos, outros 


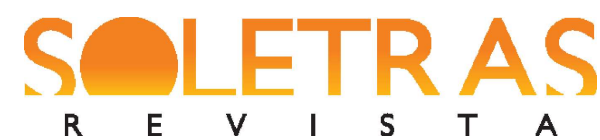

contextos, outras sociedades. Os romances de mocinho e de mocinha buscam aproximar do mundo do leitor um universo narrado de maneira fantasiosa, envolvente e gratificante. Em vista disso, é necessário um aparato teórico que não tome a narrativa de massa como um fantasma, mas que procure responder a suas relações com o consumidor. Por outro lado, ainda que os interesses econômicos e ideológicos que cercam o segmento popular constituem uma das faces do fenômeno consumista, criado por essa indústria mercadologicamente aparelhada, é preciso reconhecer que um produto desse meio não é uma mercadoria qualquer, e analisá-lo não se reduz a considerar o controle econômico, social, cultural, político e psicológico inerentes ao consumo dessas coleções estudadas - elas precisam também ser estudadas como objetos que produzem efeitos de sentido de caráter literário.

A necessidade de uma postura crítica não só em relação ao consumo de narrativas de massa, mas também às próprias narrativas consumidas, torna-se evidente. Trata-se de um problema para a crítica social e para a crítica literária - simultaneamente. Por outro lado, uma generalização da leitura crítica desses textos narrativos (que pedem com urgência tal leitura) provavelmente em pouco tempo destruiria o próprio mercado desses romances, inviabilizando a indústria.

\section{Referências}

BAKHTIN, Mikhail. "O Romance Polifônico de Dostoiévski e seu Enfoque na Crítica Literária”. In: Problemas da poética de Dostoiévski. Tradução Paulo Bezerra. Rio de Janeiro: Forense-Universtiária, 1981, pp. 1-37.

BAKHTIN, Mikhail. Questões de literatura e de estética: A teoria do romance. Tradução Aurora Fornoni Bernardini et al. 5 ed. São Paulo: Hucitec Annablume, 2002.

BAKHTIN, Mikhail. "Tipologia histórica do romance”. In: Estética da criação verbal. Tradução Paulo Bezerra. São Paulo: Martins Fontes, 2003.

BAKHTIN, Mikhail. "O problema do romance de educação". In.: Estética da criação verbal. Tradução Paulo Bezerra. São Paulo: Martins Fontes, 2003a, pp. 217-224.

BIALLY, Barbara. Os eleitos da morte. São Paulo: Fittipaldi, 1995, 128 p., (Coleção Pocket Suspense Ouro, n. 2). 


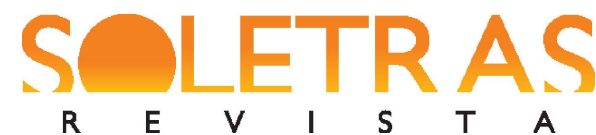

N. 40 - 2020.2 - CLEIRY DE OLIVEIRA CARVALHO

CABANHE, Oldemar. "A Leitura popular dos romances de farwest em Campo Grande: o texto e seu uso". Campo Grande: Revista Rabiscos de Primeira, v. 4, n. 4, pp. 49-58, março de 2004.

CARRIGAN, Lou. Jenny “mata-homens". Tradução Sonia Maria Rodrigues Oliveira. Rio de Janeiro: Monterrey, 1987, 128 p., (Coleção Chumbo Grosso, n. 64).

CARSON, Tony. Mulher fatal. São Paulo: Fittipaldi, 1995, 128 p., (Coleção Pocket Policial Diamante, n. 1).

COMBY, T. Herança amarga. Rio de Janeiro: Monterrey, 1980, 125 p., (Coleção Oeste Pra Valer).

COOPER, James Fenimore. O último dos Mohicanos. Tradução e adaptação para juventude por Hélcio de Oliveira Coelho. Clássicos da juventude. Belo Horizonte: Itatiaia, 1963.

CURTIS, Donald. Condenado a viver. Tradução Darcy Simas. Rio de Janeiro: Monterrey, 1997a, 128 p., (Coleção Oeste Proibido, n 159).

CURTIS, Donald. Covil do chacal. Capa de Benício. Tradução Darcy Simas. Rio de Janeiro: Monterrey, 1997, 126 p., (Coleção Lei do revólver, n 7).

CURTIS, Donald. O dragão de ouro. Tradução Darcy Simas. Rio de Janeiro: Monterrey, 2000, 128 p., (Coleção Tiroteio, n. 234).

ESCARPIT, Robert. Sociologia da Literatura. Tradução Anabela Monteiro e Carlos Alberto Nunes. Lisboa: Arcádia, 1969.

GAGNEBIN, Jeanne Marie. "Walter Benjamin ou a história aberta". In BENJAMIN, Walter. Magia e técnica, arte e política, $7^{\mathrm{a}}$ ed. São Paulo: Brasiliense, 1994, pp. 7-19.

INOUE, Georges K. R. "Ryoki Inoue: Biografia". Disponível em: $<$ http://www.ryoki.com.br/biografia.htm>. Acesso em: 12 de jan. de 2020.

JUNQUEIRA, Mary A. James Fenimore Cooper e a Conquista do Oeste nos Estados Unidos na primeira metade do século XIX. Diálogos, DHI/UEM, v. 7. pp. 11-24, 2003.

KAPRA, Peter. Legado maldito. Tradução Sebastião da Cunha e Castro Filho. Rio de Janeiro: Monterrey, 1998, 128 p., (Coleção Chumbo Quente, n. 73).

KIENTZ, Albert. Comunicação de massa: análise de conteúdo. Tradução Álvaro Cabral. Rio de Janeiro: Eldorado (Coleção Médium), 1973.

KING, Frank. Estranha aventura. São Paulo: Fittipaldi, 1994, p. 128, (Coleção Série Pocket Policial Ouro, n. 1).

KUNERT, Günter. "A abolição da cultura pela civilização: A perda de importância da leitura e da escrita”. Sobre o papel da leitura. Humboldt, Hamburgo 22:4-5, 1970. 
LONGO. Dáfnis e Cloé. Tradução Denise Bottmann. Campinas: Pontes, 1990.

MACKENZIE, Steve. Sede de sangue. Tradução Carla Romanelli. Rio de Janeiro: Monterrey, 2004, 94 p., (Coleção Oeste Vermelho - Série Verde, n. 2).

MEYER, Marlise. Folhetim - uma história. São Paulo: Cia. Das Letras, 1996.

MONROE, James. Encontro com a morte. Rio de Janeiro: Monterrey, 1990, 126 p., (Coleção Oeste Brutal, n. 206).

O’BRIAN, Edward J. Dance of the machines. New York: Macauley: 1929.

ORTUSOL, D. Um pecado atual. Rio de Janeiro: Monterrey, s/d, 124 p., (Coleção Desiré, n $1)$.

SAAVDROVITCH, M. Fui capitão do Afrika Korps. Rio de Janeiro: Monterrey, s/d, (Coleção $\mathrm{HH})$.

TILLBIT, Lilly. O garanhão. Rio de Janeiro: Monterrey, 2004, 94 p., (Coleção Reis do Gatilho, n. 25).

\title{
A panoramic study of the pocketbooks produced for the male audience: The "good-guy novel"
}

\begin{abstract}
In this article I present an overview of the novel printed on newsprint and sold in Brazil at a low price for mass consumption by an ideally male audience. The panorama is based on the reading of 101 novels from different collections and publishers, their paratexts, and secondary sources. In other words, it is a study of the contemporary "good-guy novel", inserted in a globalizing publication process; it is also a reflection on the production of entertainment, on the one hand and, on the other, the effects that this entertainment can have on the consumer. The stories in the mass narrative literature collections aim to promote certain economic interests, without other concerns, and subject their reader to a bombardment of repetitions to the point that they end up creating the need for consumption. The characters in these stories are rigidly drawn, they do not change from beginning to end, they only reinforce an initial identity confirmed with each test they pass. After analyzing the means and ends of the industry, the formal and storyline schemes of these narratives, also seeking to identify their ideal reader, I conclude that in the literary formula that is established in these novels, the process of formation of a psychologically dependent reader-consumer is inscribed.
\end{abstract}

Keywords: Cultural industry. Mass narrative fiction. Literature: production and consumption. Reading. Novella.

Recebido em: 16 de junho de 2020.

Aceito em: 28 de julho de 2020. 